\title{
Minority languages
}

\author{
Bernardo Kolling Limberger ${ }^{1}$ \\ Universidade Federal de Pelotas, Pelotas, RS, Brazil \\ Sebastian Kürschner ${ }^{2}$ \\ Katholische Universität Eichstätt-Ingolstadt, Eichstätt, Bayern, Germany \\ Cléo Vilson Altenhofen ${ }^{3}$ \\ Universidade Federal do Rio Grande do Sul, Porto Alegre, RS, Brazil \\ Isabella Mozzillo ${ }^{4}$ \\ Universidade Federal de Pelotas, Pelotas, RS, Brazil
}

\section{Introduction}

Minority languages are not easily defined. In this issue, minority (sometimes minoritized) languages are regarded as languages or varieties used in situations in which other languages are perceived as socially dominant. In Brazil, e.g., this definition ranges from indigenous languages over afro-descendant and certain immigrant languages to sign and creole languages.

Minority languages are defined by the European Charter for Regional and Minority Languages (COUNCIL OF EUROPE, 1992; cf. also PASIKOWSKA-SCHNASS 2016) as languages that are traditionally used by a group smaller than the rest of the population within a certain territory of a given state where the official language is different from the language used by this group. Regarding the articles published in this edition, however, it is necessary to expand on this definition. With Altenhofen (2013, p. 94), we define a minority language as the opposite of a majority language (which is perceived as "ordinary" and "common"), by having a marginal position in relation to majority languages. In Brazil, for example, Portuguese is the official language of most Brazilians, and as such it is used in media, formal education, and legal

\footnotetext{
${ }^{1} \mathrm{PhD}$ in Language Studies (Pontifical University of Rio Grande do Sul - PUCRS). Adjunct Professor at the Federal University of Pelotas (UFPEL), Graduate Program of Language Studies.

Orcid: http://orcid.org/0000-0001-5504-2361. E-mail: limberger.bernardo@gmail.com.

${ }^{2} \mathrm{PhD}$ in German and Scandinavian linguistics (Albert-Ludwigs-Universität Freiburg im Breisgau). Full Professor of German Linguistics at the Catholic University of Eichstätt-Ingolstadt.

Orcid: http://orcid.org/0000-0001-6364-045X. E-mail: sebastian.kuerschner@ku.de.

${ }^{3} \mathrm{PhD}$ in German studies (Johannes Gutenberg-Universität de Mainz). Full Professor at the Federal University of Rio Grande do Sul (UFRGS), Graduate Program of Language Studies.

Orcid: http://orcid.org/0000-0002-7465-6542. E-mail: cleo.altenhofen@ufrgs.br.

${ }^{4} \mathrm{PhD}$ in Language Studies (PUCRS). Full Professor at the Federal University of Pelotas (UFPEL), Graduate Program of Language Studies. Orcid: http://orcid.org/0000-0001-8445-9174. E-mail: isabellamozzillo@gmail.com.
} 
matters. Portuguese, thus, is in a clear majority position when contrasted with all the other 238 languages spoken in Brazil - according to Ethnologue (EBERHARD; SIMONS; FENNIG, 2020). Libras, the Brazilian Sign Language (BRASIL, 2002) which is recognized as a legitimate language for communication by deaf people, is also a language used by a societal minority and perceived as rather marginal in contrast with Portuguese, which is why Libras is considered a minority language.

Minority languages do not constitute a homogenous group of languages: Some might share co-official status with the majority language in their respective regions and be present in educational or formal contexts; others have a narrower scope. Some have a long tradition in a certain region, others only reflect a rather short time span. Some go back to migration processes (cf. African and European languages in Brazil), others do not (indigenous languages). Some are regionally bound, others not. Some only exist as minority languages (cf. indigenous languages in Brazil today), others are minority languages in certain states or regions, but majority languages in others (cf., e.g., German, Polish, or Italian in Brazil compared with their status in some European countries). Minority languages share characteristics with dialects in frequently being marked by the presence of some sort of subordination to a majority language or standard variety (ALLARDT, 1984). Moreover, minority languages are very often linked with bilingualism and multilingualism, as it is increasingly unlikely to find monolingual speakers of a minority language.

This issue aims to focus on minority languages and increase their visibility with a range of studies concerning many different kinds of minority languages: indigenous languages, immigrant languages, creole languages, an indigenous Portuguese variety, and (emerging) sign languages. Most minority languages discussed in this volume are located in Brazil, but this edition also includes languages located on other continents, including Africa, Asia, and Europe. The following languages are studied in this issue: Aikanã, Polish, Pomeranian, Hunsrückisch, Bohemian, Cena, Wa'ikhana, Portuguese Sateré-Mawé, Libras, Talian, Karajá, Kabuverdianu, Portuguese Tapuia, Akwẽ, Pyhcop Cati-Ji, Apinayé, Apyãwa, Iny, Itya Mahãdu, Krahô, Lebanese Arabic, Kheuól, Angolan Sign language, Cape Verdean Sign Language, Guinea-Bissau Sign Language, Mozambican Sign Language, Portuguese Sign Language, São Tomé and Príncipe Sign Language, Timorese Sign Language, Hakka and Japanese.

We received a high number of submissions subject to an anonymous review process. The great number of submissions for this issue reflects the broad range of perspectives from which minority languages can be investigated, and that minority languages are a fruitful source of research with respect to contents, methodology, and theory. The 23 papers published in this volume were approved by two reviewers. They reflect the multilingualism policy of the Journal Linguagem \& Ensino by being written in Portuguese, English, and German.

The articles document mainly empirical, but also theoretical studies. We categorized them into five groups. The first group reports studies on phonetic and phonological aspects of minority languages and on bilingualism including a minority language (studies on language contact). The second group of studies includes articles on syntactic and lexical aspects of 
minority languages, considering geolinguistic, language contact, structural and sociolinguistic perspectives. The third group of studies considers specific characteristics of bilingualism including a minority and a majority language, such as code-blending and code-switching. The fourth group includes articles about the teaching and learning of languages (either minority languages or languages in contact in diverse contexts). The articles that close the issue tackle language policy and language revitalization.

The first article published in this volume reports a theoretical study about the phonological vowel system of the Brazilian indigenous language Aikanã. Based on previous studies, Patrícia Tondineli shows a complex phonological vowel system of this strongly endangered language with only approximately 200 speakers. The second article focuses on the phonetic segment / / produced by bilinguals from a Brazilian community of speakers of Polish as an immigrant language. Giovana Ferreira-Gonçalves and Aline Rosinski provide acoustical and articulatory analyses of the lateral consonant in postvocalic position using ultrasound images. The authors show that the segment is uniquely characteristic of the immigrant language. The third article reports a study conducted by Felipe Bilharva da Silva. The study aims to investigate the influence of Pomeranian, a Low German immigrant language used in Brazil, on the production of svarabhaktic vowels in the Portuguese variety spoken in a Pomeranian-based community. The short vowel fragments investigated are found within consonant clusters with [I] or [r]. The results confirm Pomeranian influence on the production of svarabhaktic vowels. The last article included in this category is also about language contact. Claudia Camila Lara analyses devoicing processes in plosives in the production of a Portuguese variety shaped by contact with the German immigrant language Hunsrückisch. The author studies the relation between language attitudes and variation in the production of plosives, identifying a number of factors relevant in this context, such as schooling and culture.

Hunsrückisch is also the focus of the first article of the second group of studies. The article by Fernando Hélio Tavares de Barros analyzes lexical variation. He found 34 lexical variants meaning 'pumpkin' in the Hunsrückisch lexical repertoire. The lexical variation reveals both language contact and neologisms as mechanisms for expanding the lexicon. Bohemian varieties of German are in the focus of the next article. Sebastian Kürschner and Angélica Prediger analyze data from locations shaped by immigration from Northern Bohemia in Rio Grande do Sul, Brazil. The authors document a questionnaire study on lexical variation, including elicitation data and meta comments. The results show that complex contact situations shaped the development of the varieties.

The next paper presents a preliminary description of the linguistic structure of Cena, an emerging sign language in the interior of Piauí (Brazil) used by approximately 30 people. Anderson Almeida-Silva and Andrew Ira Nevins describe the language regarding lexicon, phonology, morphology, syntax, and variation, and point out directions for future research. The next article, written by Bruna Cezario, analyzes the complex linguistic phenomenon of evidentiality in the indigenous language Wa'ikhana (Eastern Tukanoan), spoken by about 1800 individuals in Brazil. Using qualitative primary data and corpus analysis, the study 
classifies Wa'ikhana evidentials in four categories, based on semantic and syntactic criteria, and highlights different functions of these elements. Hellen Cristina Picanço Simas and Dante Lucchesi focus on another indigenous language group, Portuguese Sateré-Mawé, located in the Brazilian Amazon. The authors identify morphosyntactic traces of this variety which supposedly derived from language contact. The paper also provides a socioeconomic, demographic, and ethnographic description of the Sateré-Mawé people and discusses the Indigenous Portuguese concept.

The third group of studies begins with an article by Sabine Gorovitz and Leydiane Ribeiro Duarte. Based on sociolinguistic theories, the authors analyse occurrences of codeblending in Libras-Portuguese bilinguals. They present data of spontaneous language production extracted from publicly accessible videos, identifying sociolinguistic factors that influence the use of code-blending. In addition to code-blending, code-switching is also a common phenomenon of language use in minority situations. Ariela Fátima Comiotto, Mailce Borges Mota and Eduardo Correa Soares study speakers of the Brazilian immigrant language Talian. To analyze the processing costs of code-switching activities, the authors designed a figure naming task in which the participants were asked to name the figures in a given language that was indicated by a flag, with or without code-switching. The results suggest that when two languages are freely available to a speaker, the cost of processing the heritage language is lower, because it is the more commonly used language in the community.

The fourth group of studies includes articles about the teaching and learning of languages. Caroline Pereira de Oliveira, Rogério Vicente Ferreira and Vanessa Hagemeyer Burgo discuss the acquisition process of Karajá as an L2. The authors observe bilingual practices in the community and highlight the actions promoted by Karajá people to maintain their own language, culture, values, tradition, and knowledge. Karajá, an ethnic language of Brazil, is acquired both in specialized social spaces and in daily life contexts. In the next article of this thematic group, Isaias dos Santos Ildebrand, Cátia de Azevedo Fronza and Simone Weide Luiz report a study about a teaching activity in Portuguese language classes, integrating the minority language Libras. Students and teachers were mobilized to solve problems using Libras and design thinking. In another study including Libras, Quintino Martins de Oliveira and Francisco José Quaresma de Figueiredo analyze the interactions between hearing and deaf students to identify the strategies hearing participants used to assist the deaf participants in learning written Portuguese during face-to-face tandem sessions. Additionally, the deaf students' perception of their participation in these sessions was studied. The results indicate that the tandem approach is also favorable in the tutoring process of Portuguese for deaf people. The study carried out by Tânia Ferreira Rezende and Eunice da Rocha Moraes Rodrigues aims to discuss the status of Intercultural Portuguese (language of intercultural relations among many tribes) in the Intercultural Education course at a Brazilian university. The languages included in the research are Portuguese Tapuia (Tapuia), Akwẽ (Xerente), Pyhcop Cati-Ji (Gavião), Apinayé (Apinajé), Apyãwa (Tapirapé), Iny (Karajá), Itya Mahãdu 
(Javaé) and Krahô (Krahô). The results show that the decolonial intercultural dialogue in the relations of linguistic power is related to the domination strategies of the dominating forces.

In the next article, Ronny Beckert analyzes the controversial introduction of the creole language Kabuverdianu into the education system of Cape Verde, based on responses to an online questionnaire and on comments from readers of online articles. In another paper regarding the insertion of a language into a specific context, Neiva de Aquino Albres discusses Libras. The author aims to investigate the different spaces for Libras in artistic performances and in translation and interpretative processes. The results show a growth of the artisticcultural context as a playing field for deaf people and Libras-users in Florianópolis, Brazil. In the last article of this group, Cristiane Horst and Marcelo Jacó Krug discuss the challenges of being multilingual since childhood (e.g., myths about bilingualism, language prejudices, and lack of a language policy) based on a case study in which Hunsrückisch comes into contact with German as a foreign language and Portuguese.

In the last group of articles, Isabella Mozzillo and Karen Pupp Spinassé present the results of research carried out with five bilingual individuals each speaking a Brazilian minority language: Polish, Hunsrückisch, Pomeranian, Talian and Lebanese Arabic. Based on results of a questionnaire or an interview, the authors assume that the linguistic ideologies and policies could be under influence of myths and concepts that give the minority language a negative status. Another study about language policy is concerned with the indigenous language Kheuól. Romário Duarte Sanches and Kelly Cristina Nascimento Day discuss the different language policies in the indigenous villages located in the border region between Brazil and French Guiana. The results of the analysis provide valuable information about language practices and about the maintenance of Kheuól that is useful for public authorities. In the next article, Fabiany Corrêa Basoni and Pedro Henrique Witchs, discuss language policies for deaf people in Portuguese-speaking countries. The authors analyze official documents that regulate the following sign languages in eight countries: Libras, Angolan Sign language, Cape Verdean Sign Language, Guinea-Bissau Sign Language, Mozambican Sign Language, Portuguese Sign Language, São Tomé and Príncipe Sign Language and Timorese Sign Language. The results show that the sign languages remain officially invisible in some countries, and their use and teaching are yet to be legally supported. The study by Teresa Wai See Ong is related to language maintenance of the Hakka language in Malaysia, where 134 languages are spoken (EBERHARD; SIMONS; FENNIG, 2020). The author analyzes language practices, ideology, and community-based initiatives to maintain the language in Penang and provides new insights into the process and prospects of language maintenance. Last, but not least, the article written by Leiko Matsubara-Morales provides a historical overview of Japanese as an immigrant language in Brazil. The author studies Japanese language teaching in the descendant communities and as an L2 in Brazil in relation to cultural aspects. The article situates the reality of teaching Japanese and makes suggestions for a future agenda of educational politics, including the effects of technology and globalization. 
It is our hope that the selection of papers published in this issue helps to further our understanding of the diversity of topics, languages, areas, approaches, and research methods that are linked with minority languages. In addition, we hope that the topics presented in this issue stimulate further research on the topic of minority languages by researchers in different stages of their careers and in a wide range of research areas, and helps to connect researchers, establishing and deepening collaboration in this field. We thank the authors for their interesting contributions, the reviewers for their valuable evaluations and inspiring comments, and the readers for their interest in such a broad and fascinating topic.

\section{References}

ALLARDT, E. What constitutes a language minority? Journal of Multilingual and Multicultural Development, v. 5, n. 3-4, p. 195-205, 1984. https://doi.org/10.1080/01434632.1984.9994151

ALTENHOFEN, C. V. Bases para uma política linguística das línguas minoritárias no Brasil. In: NICOLAIDES, C.; SILVA, K. A.; TílIO, R; ROCHA, C. H. (Org.) Política e Políticas Linguísticas. Campinas: Pontes Editores, 2013. p. 93-116.

BRASIL. Lei no 10436, de 24 de abril de 2002. Dispõe sobre a Língua Brasileira de Sinais - Libras e dá outras providências. Brasília, 24 de abril de 2002, 181ㅇ da Independência e 114으 da República.

COUNCIL OF EUROPE. European charter for regional or minority languages. European Treaty Series, n. 148, p. 1-14, 1992.

EBERHARD, D. M.; SIMONS, G. F.; FENNIG, C. D. (eds.). 2020. Ethnologue: Languages of the World. Twenty-third edition. Dallas, Texas: SIL International. Online version: https://www.ethnologue.com/country/BR. Accessed on Sep 1st, 2020.

PASIKOWSKA-SCHNASS, M. Regional and minority languages in the European Union. European Parliamentary Research Service, p. 1-12, 2016. 